\title{
Bokavia Sebagai Alternatif Media Pembelajaran Pada Olahraga Petanque
}

\author{
Fajar Awang Irawan, Oktavia Pratiwi Diah Ayu Pangesti \\ Jurusan Ilmu Keolahragaan, Fakultas Ilmu Keolahragaan, \\ Universitas Negeri Semarang, Indonesia
}

Diterima: 17 Oktober 2019. Direvisi: 09 Desember 2019. Disetujui: 23 Juli 2020

\begin{abstract}
ABSTRAK Siswa tingkat sekolah dasar mengalami kesulitan dalam bermain petanque karena bola besi terasa berat saat dimainkan. Tujuan penelitian ini untuk memberikan alternative media permainan melalui modifikasi bola petanque yang lebih murah, ringan, praktis, dan menarik tetapi tetap standar. Penelitian ini menggunakan 10 orang dalam uji coba kecil dan 20 orang dalam uji coba besar dengan rentang usia 8 sampai 10 tahun. Hasil dari penelitian ini pada uji coba skala kecil diperoleh $84 \%$ spesifikasi produk pada kategori baik dan $90 \%$ relevansi produk juga pada kriteria baik. Untuk uji coba skala besar diperoleh $88 \%$ spesifikasi pada kategori baik, sedangkan relevansi produk $92 \%$ pada kategori baik pula. Hasil lain pada komentar ahli ditemukan $94.15 \%$ untuk kualitas produk Bokavia pada kategori sangat baik dan $96.65 \%$ untuk spesifikasi produk juga pada kategori sangat baik. Kesimpulan yang didapat bahwa Bokavia ini layak digunakan untuk bermain petanque dan juga sebagai alternative pilihan dalam pembelajaran.
\end{abstract}

Kata Kunci: Petanque, modifikasi, bokavia.

ABSTRACT Elementary student felt difficult when playing petanque because of the weight. The aim of this study was to give media alternative using petanque ball modification that more cheap, light, and interesting as petanque standard. This study using 10 participants in small-scale and 20 participants in largescale with the mean age 8 to 10 years old. Result of this study found that $84 \%$ product specifications in small-scale was good and $90 \%$ product relevance was also in good category. Largescale data found $88 \%$ product specification in $88 \%$ and $92 \%$ relevance product was good in category. Results from the expertise found that $94.15 \%$ for product quality was very good and $96.65 \%$ product specification was also very good. The conclusion stated that Bokavia suitable for was petanque and also as an alternative choice for learning.

Keywords: Petanque, modification, bokavia

\section{PENDAHULUAN}

Olahraga merupakan suatu bentuk aktivitas fisik yang terencana dan terstruktur dengan melibatkan gerakan tubuh secara berulang - ulang dan bertujuan untuk meningkatkan kebugaran jasmani. Olahraga juga merupakan alat untuk merangsang pertumbuhan dan perkembangan jasmani, rohani dan sosial. Sehing- ga kemampuan seseorang akan diketahui bila orang tersebut sudah sehat dalam segi jasmani dan rohani. Pada saat ini peran iptek sangatlah penting dalam memajukan olahraga pada suatu bangsa (Irawan \& Sandiyudha, 2018). Seiring dengan majunya teknologi dan ilmu pengetahuan, setiap orang harus siap untuk menghadapi tantangan dengan meningkatkan dan memelihara kesegaran jasmani mereka sendiri (Irawan, 2011). Dengan demikian olahraga dapat memberikan peluang dan potensi untuk mendapatkan prestasi terutama pada olahraga petanque.

Menurut Confederation Mondiale Sport Boules (Petanque, 2002) dalam Agustina \& Priambodo, (2017), Petanque adalah sebuah permainan dengan boules / bola yang tujuannya melempar bola besi sedekat mungkin dengan bola kayu yang disebust Jack dan kedua kaki harus berada di lingkaran kecil (Circle). Nomor pertandingan dalam petanque juga menampilkan nomor khusus yaitu untuk shooting. Nomor ini difokuskan hanya pada akurasi tembakan pada bola yang telah ditentukan posisinya. Petanque sudah menjadi salah satu olahraga yang bergengsi di luar negeri, tidak hanya di eropa seperti Perancis dan Madagaskar tetapi juga sudah merambah ke negara asia seperti Jepang, Korea, Cina, dan Taiwan. Perkembangan petanque di Indonesia lambat laun menjadi semakin eksis dengan banyaknya kejuaraan dan kompetisi diberbagai daerah. Untuk meningkatkan prestasi di Jawa Tengah Pengurus Provinsi Federasi Olahraga Petanque Indonesia (FOPI) banyak mengadakan sosialisasi daerah - daerah di Jawa Tengah. Dalam menunjang prestasi selain pada faktor teknik, sarana dan prasarana yang dimiliki juga merupakan hal mendasar yang dibutuhkan dalam mendukung sebuah prestasi pada olahraga petanque. 
Penyediaan sarana dan prasarana bagi pembinaan prestasi baik ditingkat Nasional maupun daerah merupakan bagian yang penting dari keberhasilan pembinaan prestasi olahraga.

Sarana Prasarana yang sesuai dengan standar Federation Internationale de Petanque et jeu Provencal (FIPJP) yaitu bola besi dengan ukuran diameter 70,5 mm - 80,0 mm dan berat sekitar 600 - 800 gram (Petanque, 2002). Tetapi untuk anak usia 8 - 10 tahun belum memiliki standar dan kemampuan maksimal dalam melempar bola petanque. Anak usia 8 - 10 tahun disebut dengan masa permulaan atau pra-puber dimana pada tahap ini penekanan aktivitas pada pengembangan kemampuan dasar secara menyeluruh dan menyenangkan dengan intensitas latihan yang rendah melalui konsep bermain (games). Kemampuan fisik yang dimiliki merupakan dasar dan menjadi karakter pada setiap orang dalam mengembangkan kemampuannya. Materi yang diberikan berupa kemampuan ketrampilan gerak dasar dan kemampuan teknik dasar dalam bermain petanque. Kemampuan dan kebutuhan anak pada setiap cabang olahraga itu berbeda - beda. Oleh karena itu olahraga perlu dikembangkan dengan cara modifikasi olahraga.

Menurut Komaruzzaman, (2017) dalam perkembangan prestasi olahraga petanque di Jawa Tengah menemukan bahwa perkembangan olahraga petanque di Jawa Tengah dan prestasi yang sudah diraih untuk jangka waktu satu setengah tahun perlu adanya kesiapan sarana prasarana. Kendalanya adalah pada penyediaan peralatan seperti bola yang masih di import dan daerah yang kurang tanggap terhadap sarana dan prasarana seperti lapangan. Selain penelitian kommaruzzaman, pada penelitian Laksana, Pramono, \& Mukarromah, (2017) juga mengungkapkan hal tentang sarana dan prasarana dalam olahraga petanque. Data tersebut menyebutkan bahwa sarana dan prasarana sesuai standar dunia cabang olahraga sangat penting karena berpengaruh terhadap kualitas alat yang digunakan dalam latihan, sehingga dibutuhkan suatu perangkat alat yang mudah didapat dan harganya ekonomis.

Selain sarana dan prasarana olahraga petanque juga didukung dengan teknik dan kemampuan pemain dalam melempar bola petanque. Pada penelitian Akhromawati, (2018) tentang tingkat konsentrasi dan koordinasi mata tangan untuk ketepatan shooting petanque dapat disimpulkan bahwa konsentrasi dan koordinasi mata tangan merupakan komponen dan kondisi fisik yang dapat mendukung shoo- ting pada olahraga petanque. konsentrasi dan koordinasi dalam shooting petanque akurasi yang memiliki kontribusi terhadap peningkatan kinerja atlet (Irawan, Permana, Akromawati, \& Yang-tian, 2019).

Bermain petanque tidak mengenal batas usia. Pemain bisa berasal dari pelajar SD hingga mahasiswa, bahkan guru dan kalangan elit juga tidak ragu untuk turun kelapangan untuk bermain. Di Jawa Tengah total lapangan petanque yang dimiliki berjumlah 13 lapangan, itupun belum termasuk lapangan latihan yang berada diluar pengcab petanque. Beberapa atlet juga memliki keterbatasan pada sarana dan prasarana seperti bola petanque. Bola petanque di sekitar Jawa Tengah masih belum diperjual belikan secara umum di toko - toko olahraga. Bola petanque yang diperoleh merupakan produk import dari beberapa negara ke Indonesia dan jumlahnya pun terbatas. Alasan yang membuat bola petanque tidaklah murah dan tidak mudah untuk di dapatkan tersebut menjadi penghambat seseorang yang tertarik untuk mencoba olahraga petanque ini. Hal lain yang menjadi permasalah dalam pembibitan adalah massa bola yang dirasa sangat berat untuk dipegang bagi siswa Sekolah Dasar. Tujuan dalam penelitian ini adalah untuk memberikan alternative media permainan melalui modifikasi bola petanque yang lebih murah, ringan, praktis dan menarik tetapi tetap sesuai dengan standar permainan petanque.

\section{METODE}

Penelitian ini merupakan penelitian pengembangan atau research and development (R\&D). Penelitian pengembangan dalam hal ini memiliki tujuan untuk menghasilkan suatu produk melalui prosedur yang khas dengan diawali dengan need assessment, atau analisis kebutuhan, dilanjutkan dengan proses pengembangan dan diakhiri dengan evaluasi (Sugiyono, 2009). Penelitian pengembangan ini dilakukan di SD N 02 Plajan kecamatan Jepara, kabupaten Jepara. Populasi dalam penelitian ini berjumlah 30 siswa yang berusia 8 - 10 tahun. Pada uji coba skala kecil total partisipan berjumlah 10 siswa, dan 20 partisipan digunakan pada uji lapangan. Instrumen penelitian ini dibagi menjadi 3 bagian yang digunakan untuk mengevaluasi produk yang dibuat dan mengetahui kelayakan dari produk tersebut yaitu : Instrumen uji kelayakan untuk ahli materi petanque, instrumen uji kelayakan untuk ahli Pembelajaran, dan instrumen uji kelom- 
pok kecil untuk siswa. Instrumen yang digunakan dalam penelitian pengembangan ini menggunakan dokumentasi, dan kuesioner.

Teknik analisis data yang digunakan dalam penelitian pengembangan ini dengan menggunakan teknik analisis deskriptif kuantitatif yang berbentuk presentase. Sedangkan data sekunder didapatkan dari wawancara dan dokumentasi penelitian.

\section{HASIL DAN PEMBAHASAN}

Hasil penelitian ini memuat tentang modifikasi bola petanque dengan media kayu (Bokavia) untuk anak usia 8 - 10 tahun. Detail informasi dan penjelasannya disampaikan pada pembahasan dibawah ini. Produk Bokavia terbuat dari bahan kayu mahoni, berdiameter 65 mm dan memiliki berat 80 - 110 Gram. Bokavia ini tepat digunakan untuk anak usia 8 - 10 tahun karena berat saat digenggam sangat sesuai dengan anak usia sekolah dasar.

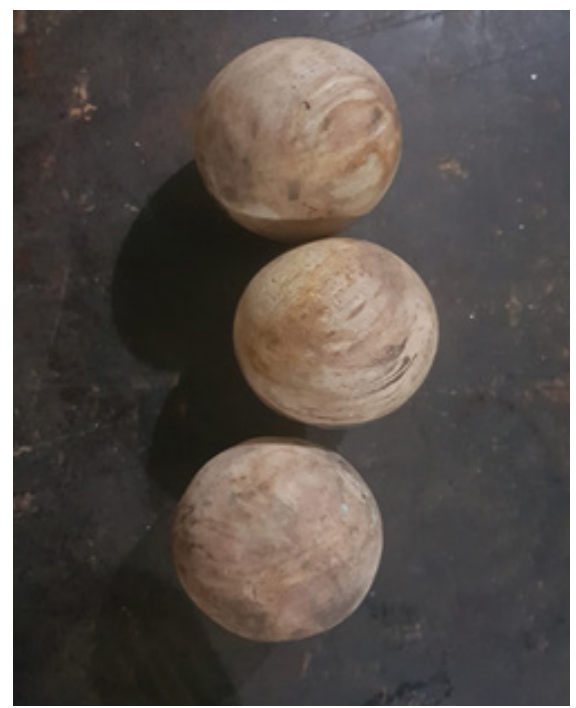

Gambar 1. Bola BOKAVIA

Gambar 1 menjelaskan secara detail tentang bahan dan ukuran Bokavia. Spesifikasi bola modifikasi ini sama seperti bola petanque sebenarnya, perbedaanya pada material bahan yang terbuat dari kayu mahoni pilihan yang tidak mudah berubah dan awet serta massa bola yang sesuai untuk pembelajaran.

Kelayakan produk penelitian ini dinilai oleh 2 pakar yang memiliki keahlian pada petanque dan ahli pembelajaran untuk memastikan instrument sudah layak untuk digunakan. Hasil validasi dari ahli materi petanque diperoleh nilai rerata $94.15 \%$ untuk kualitas produk pada bola petanque dan termasuk dalam kate- gori "Sangat Baik". Validasi ahli pembelajaran ini menggunakan kuesioner yang berisi tentang relevansi produk dan spesifikasi produk. Dari hasil validasi ahli pembelajaran diperoleh skor rerata $96.65 \%$ untuk aspek spesifikasi dan relevansi produk dan termasuk dalam kategori "Sangat Baik".

\section{Respon Terhadap Bokavia}

Modifikasi bola petanque dengan media kayu ini di peruntukan untuk anak 8 - 10 tahun. Untuk mengetahui respon partisipan dilakukan ujicoba skala kecil dan uji coba skla besar. Uji coba skala kecil dilakukan dengan melakukan lemparan bola petanque (Bokavia) yang dimodifikasi sebanyak 5 kali lemparan, dilakukan oleh 10 partisipan yang berusia 8 10 tahun. Uji coba skala besar dengan menggunakan jumlah sampel yang lebih banyak dengan tetap bermain menggunakan Bokavia sebanyak 20 partisipan yang berusia antara 8 - 10 tahun. Dari hasil uji coba skala kecil diperoleh skor rerata yaitu $84 \%$ untuk spesifikasi produk dan termasuk dalam kategori Baik, sedangkan untuk relevansi produk pada uji coba kelompok kecil diperoleh nilai rerata yaitu 90\% dan termasuk dalam kategori Sangat Baik. Hasil penelitian ini dapat dilihat pada Gambar 2.

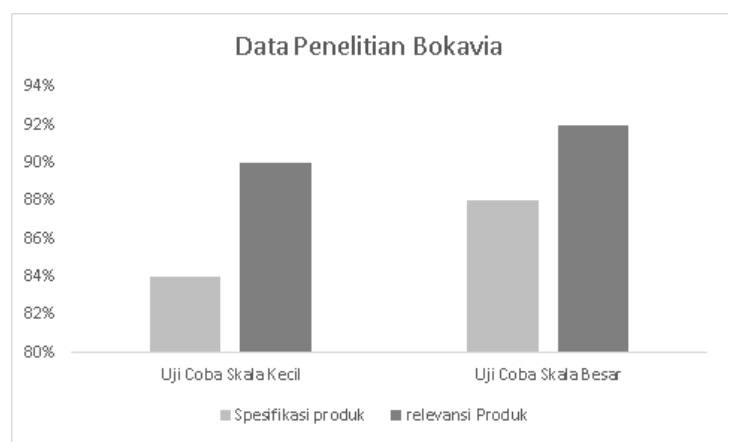

Gambar 2. Hasil uji coba skala kecil dan uji coba skala besar

Hasil uji coba skala besar diperoleh $88 \%$ pada spesifikasi produk pada kategori Sangat Baik. Sedangkan untuk relevansi produk pada uji coba skala besar diperoleh rata-rata 92\% pada kategori sangat baik.

Bokavia dalam penelitian ini merupakan modifikasi dari bola petanque yang terbuat dari kayu yang dibuat persis menyerupai bola petanque sesungguhnya, hanya saja berat bokavia lebih ringan dari bola besi (bosi). Nama bokavia sendiri diambil dari nama penemu produk ini dan dijadikan sebagai ikon dalam istilah penamaan suatu produk media bola un- 
tuk bermain petanque. Bokavia dapat dimainkan pada tanah berpasir, berkrikil, berpaving, aspal, lantai dan rumput. Selain itu bokavia juga memiliki bahan yang padat dan keras tetapi tidak merusak alas atau lapangan yang digunakan untuk bermain. Bokavia sendiri terbuat dari bahan kayu mahoni, berdiameter $65 \mathrm{~mm}$ dan memiliki berat sekitar 80 - 110 gram. Bokavia ini sama seperti bola besi yang digunakan dalam bermain petanque dengan 1 setnya berjumlah 3 bola berukuran besar dan 1 buah bola berukuran kecil untuk digunakan sebagai Jack.

\section{Kelayakan Bokavia}

Modifikasi bola petanque ini juga dilakukan untuk mengetahui kelayakan produk Bokavia dengan menggunakan 2 validator yang berkompeten dalam menilai layak atau tidaknya produk ini digunakan. Validasi dilakukan untuk menilai materi permainan dan kesesuaian dalam pembelajaran. Validasi ini dilakukan dengan memberikan produk modifikasi bola petanque yang disertai dengan manual book dan lembar kuesioner untuk mengetahui respon dan komentar dari para partisipan dalam memberikan respon terhadap produk Bokavia. Validasi ahli materi petanque dengan menggunakan kuesioner berisi tentang relevansi produk dan spesifikasi produk. Relevansi produk disini bermaksud untuk mengetahui seberapa layak produk yang dibuat yang sesuai dengan kebutuhan masyarakat khususnya untuk siswa sekolah dasar yang berusia 8 - 10 tahun. Sedangkan spesifikasi produk berisi tentang bagian eksternal dari produk yang meliputi bentuk, ukuran dan kondisi fisik produk supaya mirip dengan produk yang sebenarnya.

Pada penelitian sebelumnya oleh Laksana et al., (2017) tentang perspektif olahraga petanque terhadap perkembangan prestasi di Jawa Tengah. Hasil yang diperoleh adalah bahwa prestasi seseorang terkait motivasi dan pengembangan kemampuan sendiri untuk berprestasi. Dari penelitian sebelumnya terkait prestasi yang diharapkan maka perlu adanya pengembangan peralatan pendukung yang dapat meningkatkan kemampuan pemain serta daya imajinasi seseorang untuk peningkatan kemampuan teknik dasar melempar bola pada petanque. Bokavia berawal dari kegelisahan tentang pembinaan usia dini pada prestasi olahraga petanque, karena kendala peralatan yang tidak tepat pada anak usia dini maka diperlukan pengembangan peralatan yang sesu- ai dengan spesifikasi pada pemakai.

Penelitian Bokavia ini senada dengan penelitian yang diakukan oleh Sutrisna, Asmawi, \& Pelana, (2018) tentang model latihan shooting untuk pemula guna meningkatkan akurasi yang tidak stabil pada pemain muda. Inovasi guna peningkatan prestasi selalu memberikan dampak yang positif untuk pengembangan kemampuan atlet dalam memperbaiki performa dalam bermain. Keterkaitan produk tidak selalu sama, akan tetapi selalu memberikan kontribusi dalam setiap aspek yang diungkap. Agustini, Nugraheni, \& Maulana, (2018); Cahyono \& Nurkholis, (2018); Kharim \& Nurkholis, (2018); Mudhalifa, Himawanto, \& Sukmana, (2018) memiliki keterkaitan yang sama pada pembahasan dalam peningkatan kemampuan saat shooting dan pointing. Penelitian pada Agustina \& Priambodo, (2017); Irawan et al., (2019) juga memiliki ketertarikan pada akurasi dan koordinasi saat melakukan lemparan petanque. Kebermanfaatan produk dalam penelitian ini dapat membantu memfasilitasi semua masyarakat khususnya pada anak usia 8-10 tahun yang tertarik untuk bermain petanque akan tetapi memiliki kendala pada ketepatan pemakaian bola petanque sebenarnya yang dirasa berat untuk anak usia tingkat dasar. Sarana dan prasarana yang lengkap untuk pembelajaran (Irawan \& Prasetyo, 2019) akan memudahkan peserta didik untuk memaksimalkan potensi yang dimiliki terlebih lagi dalam peningkatan kemampuan. Sehingga Bokavia nantinya dapat memberikan kontribusi dalam memperjelas pemahaman baik dalam teknik dasar maupun peraturan permainan yang lebih menarik, praktis, dan ekonomis dengan tetap mengacu pada standar permaianan petanque sebenarnya.

\section{SIMPULAN}

Hasil dari penelitian ini didapatkan bahwa modifikasi bola petanque (BOKAVIA) dapat dijadikan sebagai alternatif media permainan sebagai pengganti bola petanque yang dapat digunakan untuk anak tingkat dasar. Bokavia ini dinyatakan layak untuk digunakan bermain petanque untuk anak usia 8 - 10 tahun dengan tetap mengacu pada peraturan permainan petanque sebenarnya. Penelitian selanjutnya diharapkan dapat memodivikasi peraturan permainan sesuai dengan peralatan dan lapangan permainan didalam ruangan. 
DAFTAR PUSTAKA

Agustina, A. T., \& Priambodo, A. (2017). Hubungan Antara Tingkat Konsentrasi terhadap Hasil Ketepatan Shooting Olahraga Petanque Pada Peserta UNESA Petanque Club. Jurnal Pendidikan Olahraga Dan Kesehatan, 5(3), 391-395.

Agustini, D. K., Nugraheni, W., \& Maulana, F. (2018) Hubungan Kekuatan Otot Lengan dan Koordinasi Mata Tangan Terhadap Ketepatan Shooting dalam Olahraga Petanque di Klub Kota Sukabumi Tahun 2018. In UMMI ke-1 Tahun 2018 (pp. 163-167).

Akhromawati, H. R. (2018). Tingkat Konsentrasi dan Koordinasi Mata Tangan Untuk Ketepatan Shooting Petanque. Universitas Negeri Semarang.

Cahyono, R. E., \& Nurkholis. (2018). Analisis Backswing dan Release Shooting Carreau Jarak 7 Meter Olah- raga Petanque Pada Atlet Jawa Timur. Jurnal Prestasi Olahraga, 1(1), 1-5.

Irawan, F. A. (2011). Pengembangan Permainan Kasbols untuk Pembelajaran Pendidikan Jasmani Olahraga dan Kesehatan bagi Siswa MTs NU Ungaran Tahun 2010. Jurnal Media Ilmu Keolahragaan Indonesia, 1(1), 48-51. Retrieved from http//journal.unnes. ac.id

Irawan, F. A., Permana, D. F. W., Akromawati, H. R., \& Yang-tian, H. (2019). Biomechanical Analysis of Concentration and Coordination on The Accuracy in Petanque Shooting. Journal of Physical Education, Sport, Health and Recreations, 8(2), 96-100.

Irawan, F. A., \& Prasetyo, F. E. (2019). Sport Infrastructure for Physical Education in Senior High School. International Journal of Multicultural and Multireligious Understanding, 6(1), 66-70. 